\title{
Are You on the Right Track? A New Approach to Faculty Status in the Changing Legal Environment
}

\author{
By Kama B. Pierce \\ Camille M. Davidson ${ }^{\dagger}$
}

In this article we address the institutional concerns that led to the creation of a unique approach to faculty security of position and academic freedom our institution. We provide a detailed look at our model, and how our faculty has responded after the first year of implementation. We implemented the changes at our School in the fall of 2013. In response to the cry for reform in legal education, our institution opted to rethink the traditional model of tenure and contract faculty. As we restructured our faculty, our goals were to encourage faculty members to enhance their strengths while remaining engaged in the culture of the institution. Also, we sought to promote equity across the different types of faculty members and provide what our students and institution needed to excel in the changing legal environment. After a year of research and feedback, we implemented a Track system to address the concerns raised by the faculty, administration, and legal community.

Keywords: Legal education; Track system; Tenure-Track faculty

\section{Introduction}

Our law school charged us with the creation of a unique approach to faculty security of position and academic freedom in response to the cry for reform in legal education. We implemented the changes at our School in the fall of 2013. This article will address the institutional concerns that led to our revisions, a detailed look at our model, and how our faculty has responded after the first year of implementation.

Legal education is in a crisis. ${ }^{1}$ Accordingly, for purposes of survival, law schools may need to consider changes to how faculty are defined and utilised. ${ }^{2}$ In response to the need for change, our institution opted to re-think the traditional model of tenure and contract faculty. As we restructured our faculty, our goals were to encourage faculty members to enhance their strengths while remaining engaged in the culture of the institution. Also, we sought to promote equity across the different types of faculty members and

\footnotetext{
* Associate Professor of Law, Charlotte School of Law, USA.

$\uparrow$ Professor of Law and Associate Dean for Academics and Faculty Development, Charlotte School of Law, USA.

${ }^{1}$ Stewart (2014).

${ }^{2}$ Mangan (2013).
} 
provide what our students and institution needed to excel in the changing legal environment.

After a year of research and feedback, we implemented a Track system to address the concerns raised by the faculty, administration, and legal community. Prior to the Track system, doctrinal faculty were hired as tenuretrack faculty where the teaching obligation was approximately twelve credit hours per year with a scholarship requirement. The faculty member was eligible to apply for tenure during his or her sixth year of teaching. Additionally, we had legal writing and skills faculty ${ }^{1}$ who, after probationary period, were eligible to apply for extended term contracts. Some pursued scholarship even though it was not a requirement.

All faculty participated in faculty meetings, committees, and governance issues of the institution. However, salaries were not comparable between the different types of faculty. As a result of the pay disparity, there were feelings of inequity that jeopardised the culture of the institution. Additionally, there was concern among the faculty that individual faculty members were able to make "side-deals" with the administration that resulted in continued employment when they could not meet their contractual obligations. As we contemplated changes to our faculty structure, we realised that not all doctrinal faculty excelled at scholarship. Many who struggled with scholarly output excelled at teaching. So, we gave all faculty a choice under the new system -tenure track, teaching track, or alternative track.

The faculty members on each track continue to serve on school committees, have full voting rights, participate in faculty governance issues and are eligible for rank promotion on each particular track. However, under the new system, faculty are allowed to play to their strengths (i.e. opting for more teaching time rather than focusing on scholarship) and maintain job security and eligibility for promotion. Those on the teaching and alternative tracks are eligible for extended term five year contracts rather than tenure.

Our goal was to keep the number of faculty on teaching track and tenure track as even as possible so that one track was not considered more advantageous than another track. With faculty on each track, we believe that we have balanced the security of position concerns of faculty and financial concerns of the institution. We believe that our alternative provides our students with a healthy balance of research scholars, practitioners, and teaching scholars.

We do not advocate eliminating tenure. In fact, we believe that it should and will continue to remain an important part of the academy. However we believe that our new model is a viable alternative in the "quest for a different, and possibly even better, way of protecting academic freedom and free inquiry." 2

In Part I, we discuss the Track system, including the faculty obligations and how we amended our handbook and promotion criteria; in Part II, we consider the impact of the Track system on both doctrinal and the legal

${ }^{1}$ Clinicians were primarily out of the scope of this article.

${ }^{2} \mathrm{O}$ 'Neil (2001). 
writing/skills/clinical faculty; and, in Part III, we discuss the faculty survey post-implementation and look forward at how to improve the model.

\section{PART I. The Track System}

\section{Defining the Tracks}

The Track system consists of three tracks, namely, tenure track, teaching track, and alternative track. Prior to the Track system, our faculty was similar to most schools in the Legal Academy. We had rank faculty who were either on a tenure track doctrinal path or a contractual clinical/skills/legal writing path.

The tenure track under this new system does not alter the traditional tenure track seen throughout the Academy. Our institution does require post-tenure review every four years. A faculty member on tenure track must teach approximately $12-14$ credit hours per year ${ }^{1}$, and complete at least three (3) quality law review articles within the seven (7) year probationary period in order to be considered for tenure.

Faculty members on the teaching track, in lieu of a scholarship requirement, teach an additional four (4) to six (6) credits each academic year. In return, teaching track faculty receives the same base salary as tenure track faculty.

Under the alternative track, a faculty member may opt for $12-14$ credit hours per year without a scholarship requirement. However, given the reduced obligations in comparison to the other two tracks, a faculty member on the alternative track receives a base salary that is approximately one-third (1/3rd) less than the base salary of the other two tracks. ${ }^{2}$

All faculty members attend and vote at faculty meetings; serve on school committees; and participate in faculty governance issues such as handbook changes, and faculty hiring, to name a few. Additionally, all faculty go through the same faculty hiring process which requires an on-campus interview and a job talk.

\section{The Process}

The process to develop a comprehensive and equitable system for the faculty was an intense and timely one. To our advantage, as a member of a consortium comprised of three schools, there were many faculty members from different school environments who were a part of the process for input and

\footnotetext{
${ }^{1}$ Ideally, we would like to keep our faculty at 12 credits for tenure and alternative track and 16 for teaching track but we implemented a new curriculum, Charlotte Law Edge that included requisite practice ready simulated courses in the $1 \mathrm{~L}$ year. As with any typical $1 \mathrm{~L}$ year course, the faculty wanted these courses taught by fulltime faculty. But, these courses are not typical 12-week courses but only meet three times a semester.

${ }^{2}$ Basically, this is not a salary reduction but represented the status quo for a typical legal writing or skills faculty at our institution.
} 
discussion. The restructuring of the faculty was actually part of a larger initiative called Legal Ed 2.0.

After independent research and regular discussions with faculty representatives from each consortium school, we began a process of restructuring our faculty. We posed the question on the LWI listserv and researched the ALWD/LWI Report of the Annual Legal Writing Survey to determine exactly how many schools have offered tenure for every faculty member in the school. In addition, we looked at the discussions surrounding the ABA Task Force on Legal Education that considered eliminating tenure as a requirement for law school accreditation. ${ }^{1}$ We also considered a lot of research, including research on how students learn from adjunct faculty as opposed to full-time faculty. ${ }^{2}$ Finally, we considered discussions by and alternative structures implemented in different types of educational institutions. $^{3}$

Faculty and administration input and buy-in was vital to the process. So, we frequently conducted straw polls and surveys with our faculty. We led focus groups to address specific aspects of the proposal. And, we regularly met with the school's administration for their input and to provide updates. This process was mirrored in the other schools in the consortium.

Our surveys and meetings revealed that the legal writing faculty was most concerned about equal compensation and teaching load. The doctrinal faculty was most concerned with losing academic freedom that is often associated with tenure. The clinical faculty was most concerned with how to balance their teaching and administrative duties. The administration was most concerned about the costs associated with the new system and wanting to make sure that there were real benefits to the institution. And, everyone was concerned with the increase in credit hour obligations under the new system.

The drafts were multiple as we addressed the concerns of the faculty and administration. Once we had a final draft, we presented it to the full faculty at a faculty meeting. To gauge whether the faculty supported the final draft, we conducted an anonymous survey that asked whether they would support the proposal, and if so, what track would they choose. ${ }^{4}$ Based on the results, we found there was faculty support for the proposal. About half of the faculty reported that they wanted tenure track and half reported they wanted teaching track. A small percentage (around 10\%) preferred the alternative track.

After all the feedback and the process, we felt confident to move forward with the new structure. At the end of the academic year, the Dean asked faculty to select a track. If a faculty member was already on tenure track, he or she could opt to remain on tenure, or opt for teaching or alternative track. The same

\footnotetext{
${ }^{1}$ Am. Bar Association Task Force on the Future of Legal Education, Report and Recommendations 1 (2014).

${ }^{2}$ Figlio, Schapiro \& Soter (2003).

${ }^{3}$ Schmidt (2013) A10; Newbart (1996) 1A; Feldman and Turnley (2001); Friedman (2009); Kiehl (2000) A1, and Willis (2001) A11.

${ }^{4} 10.64 \%$ choose Alternative Track, $31.91 \%$ choose Teaching Track, $12.77 \%$ choose Teaching Track with clinic/experiential, $31.91 \%$ choose Tenure Track, and $12.77 \%$ choose Professional Track. - Survey on file with author.
} 
held true for the legal writing, skills, and clinical faculty. New faculty contracts were issued with the new tracks but honoured any prior years of teaching for purposes of salary, eligibility for rank promotion, and eligibility for extended contracts and tenure.

After implementing the new structure, we had to amend our Faculty Handbook, which required a majority of the faculty vote.

\section{PART II. Tenure is not the only Track to Success}

\section{Doctrinal and Tenure}

Even though our School's mission is to deliver practice ready lawyers, we were holding on to a traditional law school faculty structure that had been around since the early part of the twentieth century. ${ }^{1}$ Although we recruited faculty who had practice experience, each doctrinal faculty member was hired on the tenure track. ${ }^{2}$ They were required to engage in scholarship, in addition to their teaching and service responsibilities. Since some faculty were not interested or engaged in scholarship, our subcommittee questioned whether this model best served our students and the individual faculty members.

Around the time of our first meeting, the media were discussing Brian Tamanaha's book, Failing Law Schools, where he criticised law school at its core. ${ }^{3}$ Also in mid-2012, the American Bar Association's Task Force on Legal Education was created and charged with addressing issues related to the current law school crisis. ${ }^{4}$ Both Tamanaha and the ABA Taskforce looked at the issue of tenure. Tamanaha claimed that the high cost of law was used to fund irrelevant faculty scholarship. ${ }^{5} \mathrm{He}$ argued for radical changes. ${ }^{6}$ The ABA Task Force made several recommendations to address the legal education crisis. One of the many proposals from the Task Force was to eliminate tenure as a requirement for law school accreditation. ${ }^{7}$ The proposal was ultimately not adopted. ${ }^{8}$ However, as we restructured our faculty, we evaluated comments related to Tamanaha's proposals and those associated with the ABA Taskforce proposal. $^{9}$

As we looked at changes to our faculty structure, we knew that tenure was valuable to many faculty. We did not want to eliminate it. However, it was not

\footnotetext{
${ }^{1}$ Dunham and Frieland (2009) 371.

${ }^{2}$ Newton (2010). 105.

${ }^{3}$ Tamanaha (2012); see also Fishman (2000) 170: "The attacks on academic tenure fall into several categories, including the financial cost and resulting inflexibility to the institution, the creation of inappropriate incentives for faculty, and the problems the result from lifetime employment. Admittedly, some of the criticisms are deserved. Almost all institutions in higher education are financially hard-pressed.".

${ }^{4} \mathrm{Am}$. Bar Association Task Force on the Future of Legal Education (2014).

${ }^{5}$ Tanamaha (2010).

${ }^{6}$ Ibid.

${ }^{7}$ AM. Bar Association Task Force on the Future of Legal Education (2014).

${ }^{8}$ Ibid.

${ }^{9}$ Holbrook, (2013).
} 
perfect. $^{1}$ At our school, like most other schools, it was not an option for all types of faculty. Our goal was to restructure our faculty in a way that was financially sound, eliminated issues of status, and recognised the strengths of each faculty member.

We framed our discussions in terms of what worked best for our students. We initially looked at tenure for all faculty. Research led us in a different direction. We considered research that suggested that undergraduate students learn more from adjuncts who were focused on teaching rather than research. ${ }^{2}$ We were also aware of those who argued that tenure was expensive and contributed to the high cost of law school. ${ }^{3}$ We wanted to strike a balance somewhere in between the two schools of thought.

\section{What is wrong with Tenure? The Big Bang Theory ${ }^{4}$}

An episode of the Big Bang Theory highlights the issues that we discussed as we evaluated the benefits of tenure and looked at viable alternatives. Although a comedy, an episode of The Big Bang Theory highlighted many of the concerns of tenure critics. ${ }^{5}$ Does tenure diminish faculty productivity? ${ }^{6}$ Does tenure mean a job for life ${ }^{7}$ Is tenure merely a popularity contest where

${ }^{1}$ O'Neil (2001) 579: "if one concedes that tenure is not perfect - and to claim imperfection, even for an unrequited defender, would be myopic - it is fair to ask how it could be made better.".

${ }^{2}$ Figilo, Schapiro \& Soter (2003).

3"Law schools devote excessive resources to faculty scholarship, which unnecessarily increases increases the cost of legal education and the related amount of law student debt." Am. Bar Ass'n Task Force on the Future of Legal Education, Report and Recommendations 1 (2014).

${ }^{4}$ Big Bang Theory: The Tenure Turbulence (CBS television broadcast Apr.4, 2013).

${ }^{5}$ Fishman (2000) 170.

${ }^{6}$ Adams (2006). "A common refrain against tenure is that it perpetuates mediocrity and results in deadwood faculty members. The first argument is that deadwood flourishes as mediocre faculty members are awarded tenure and perpetuates a culture of bad teaching, little or no scholarship, and lack of productive service." Ibid at 78; "Tenure has come under increasing attack in recent decades, both in the United States and abroad, with the main argument against tenure being that it removes incentives for productivity and unfairly relieves professors of the economic uncertainty suffered by other workers." Ibid at 71.

${ }^{7}$ Ibid. at 71:" A precise definition of tenure has been stated by Professor William Van Alstyne, former president of the American Association of University Professors (AAUP) and a faculty member at Duke Law School: "Tenure, accurately and unequivocally defined, lays no claim whatever to a guarantee of lifetime employment. Rather, tenure provides only that no person continuously retained as a full-time faculty member beyond a specified lengthy period of probationary service may thereafter be dismissed without adequate cause." Ibid. at 69-70. Fishman (2000) 170: "The attacks on academic tenure fall into several categories, including the financial cost and resulting inflexibility to the institution, the creation of inappropriate incentives for faculty, and the problems the result from lifetime employment". Hawke (1997). "Admittedly, some of the criticisms are deserved. Almost all institutions in higher education are financially hard-pressed."; "Tenure guarantees lifetime employment for faculty at an exorbitant cost to the institution that eventually results in increased tuition for students and their families.". Conrad and. Trosch (1998) 552: "The meaning of tenure as discussed in this article was best defined by Matthew W. Finkin, 'Tenure, accurately and unequivocally defined, lays no claim whatever to a guarantee of lifetime employment. Rather, tenure provides that no 
members of the tenure committee need to be schmoozed or does one's work speak for itself? ${ }^{1}$

The story line began with the death of a tenured professor. ${ }^{2}$ As the main characters began to think about applying for the open position, they explained tenure to their significant others. The first couple's dialogue was as follows: the girlfriend asked her professor boyfriend, "So tenure means a job for life?" her boyfriend responds, "Yep" "She continues with, "You can't get fired even if you're bad at it?" He responds, "Not really." right after she deadpans with "Sounds a lot like a pretty waitress at the Cheesecake factory."

The next couple's conversation was as follows: The boyfriend who was a professor stated, "While I disagree with the premise of tenure, it wouldn't diminish my output if they give it to me. I'm like the sun, I can't turn this off.",

In a humorous way, the show captured the arguments of tenure critics. Critics of tenure argue that the "hired for life" tenure imposes undue restrictions on an institution's flexibility in meeting financial demands, recruiting and hiring a younger and more diverse faculty, and making programming changes to address demands and innovations. ${ }^{8}$

Critics of tenure see it as a mechanism for protecting the "lazy and incompetent." 9 Their perception is "you can't be fired even if you are bad."10 Many argue that faculty productivity dissipates after the achievement of tenure. ${ }^{11}$ At the extreme end of criticism are those who blame tenure for much of what is wrong with American education - the results of boundless selfindulgence that results when people have guaranteed jobs. ${ }^{12}$ As for those who "can't turn it off" and continue to produce scholarship and remain in the engagement of the institution. Tenure critics suggest that these individuals do not need tenure status because their employment would not be in jeopardy. ${ }^{13}$

As discussed in Part I, we believed that there was still room for scholarship even as we reorganised our curriculum. But, we also agreed that tenure should not be the only measure of success. We made sure under our new structure that

person continuously retained as a full-time faculty member beyond a specified lengthy period of probationary service may thereafter be dismissed 'without adequate cause'."

${ }^{1}$ Adams (2006) 69. "[...] the tenure process has been criticized for denying opportunities to women and other underrepresented groups due to the application of collegiality as a criterion for selection."

${ }^{2}$ Big Bang Theory: The Tenure Turbulence (CBS television broadcast Apr.4, 2013).

${ }^{3}$ Ibid.

${ }^{4}$ Ibid.

${ }^{5}$ Ibid.

${ }^{6}$ Ibid.

${ }^{7}$ Ibid.

${ }^{8}$ Adams (2006) 92 ; Holbrook (2013) 56.

${ }^{9}$ Ibid. at 77 .

${ }^{10}$ O’Neil (2001) 580: "Thus the assertion that tenure represents an immutable guarantee of academic employment, regardless of the gravity of personal transgression or institutional need, is not only untrue but is also irresponsible."

${ }^{11}$ Adams (2006) 92.

${ }^{12}$ Robbins (1998) 388.

${ }^{13}$ Adams (2006) 92. 
our full-time faculty contract options provided each faculty member with the ability to use his or her strengths to meet the needs of a diverse population of law students.

Under our new structure, nine tenured or tenure-track faculty opted for the new Teaching track, an option that eliminated traditional scholarship and required faculty to teach more credits each Academic year. A renewable extended five year contract replaced tenure. In our initial year, tenure track faculty with more than four years of teaching experience were awarded a three year contract and the opportunity to apply for an extended-term five year contract. In other words, they were able to count their tenure track years for purposes of teaching credit. A tenured faculty member who gave up tenure was automatically granted such five year contract. Arguably, since one reaches the time period for an extended contract quicker than one reaches the end of the probationary period for tenure, the teaching track may provide security of position quicker than tenure. Some have even called it term tenure. ${ }^{1}$

We believe that our students have benefited from the diversity of our strengths as faculty. Also, the institution has the flexibility to make and implement programming changes and address demands and innovations that are necessary to succeed in the changing environment of legal education. ${ }^{2}$

\section{Security of Position and Academic Freedom}

In order to devise alternatives to tenure, we needed to define the term and look at its history. We asked ourselves whether faculty elevated the protections that tenure provides and whether the protections could be achieved in other ways.

Tenure is "a permanent contract of employment for university professors after a probationary period (usually six years) intended to guarantee intellectual freedom and independence and to shield the faculty members from the treat of termination for arbitrary or doctrinal reasons." 3 While tenure in this country has been around for almost one hundred and fifty years, it has evolved over time. ${ }^{4}$ Today the term is often used in the context of job security and academic freedom. ${ }^{5}$ When a faculty member is awarded tenure, his or her at-will employment arrangement where "an employee can be terminated for any reason" is replaced with the two specific protections: first, job security by requiring cause for termination; and second, academic freedom. ${ }^{6}$

\footnotetext{
${ }^{1}$ Fishman (2000) 194: "Most frequently offered as an alternative to traditional tenure, are longterm or rolling contracts, sometimes referred to as 'term tenure'. The faculty member is initially appointed for one to three years, with terms of reappointment eventually extended to seven or...ten years.".

${ }^{2}$ Adams (2006) 92.

${ }^{3}$ Ibid. at 73 .

${ }^{4}$ biId. at 67 .

${ }^{5} I d$.

${ }^{6}$ Ibid. at 74 .
} 


\section{Security of Position}

As faculty contemplated whether to remove themselves from tenure track (or even a tenured position) they wanted to make sure that they had job security. We wanted all faculty, regardless of the chosen track, to have security of position. Proponents of tenure believe that tenure provides security of position and security of position guarantees academic freedom. ${ }^{1}$ They rarely mention that "tenure is revocable and therefore not absolute." 2 Most faculty were vocal about how much more money they could earn in the private sector. It was job security that provided them with the comfort of foregoing the higher salaries. ${ }^{3}$ The flip side of the coin was the administration's need to ensure accountability.

While faculty wanted security, the administration wanted to ensure that each faculty member pulled his weight in the institution. While security of position benefits faculty, it can also produce "disincentives for teaching and scholarly productivity."4 A working definition that we used in our discussions was one put forth by Matthew W. Finkin that states, "Tenure, accurately and unequivocally defined, lays no claim whatever to a guarantee of lifetime employment. Rather, tenure provides that no person continuously retained as a full-time faculty member beyond a specified lengthy period of probationary service may thereafter be dismissed 'without adequate cause.", 5

The strength of our model is faculty accountability. When individuals who were not engaged in scholarship were able to keep their salary and have job security, they were more inclined to remove themselves from tenure track (or even tenure). Their decision to teach an increased course load was student outcome centred. ${ }^{6}$ As we added more skills classes to the curriculum, we needed faculty to teach the classes. As we reduced class sizes, this increased a need for faculty to teach the additional sections.

"[T]hroughout higher education there has been a movement away from tenured faculty slots through the use of non-tenure track positions.", "As faculty members do retire, many of them are being replaced by a rising number of part and full-time, non-tenure track employees." "These temporary parttimers generally receive a quarterly or semester appointment at a flat rate of pay per course taught, receive no benefits, and have no assurance of any future appointments." 9

It is not student outcome cantered when an individual divides his or her time between several part time appointments in an attempt to piece together a

\footnotetext{
${ }^{1}$ bild. at $79-80$.

${ }^{2}$ Conrad and Trosch (1998) 552.

${ }^{3}$ Adams (2005) 70:"'offsets the salary difference between those who choose an academic, as opposed to a professional or business, career."

${ }^{4}$ Ibid. at 67.

${ }^{5}$ Conrad (1998) 552.

${ }^{6}$ http://www.charlottelaw.edu/about (last visited 11/9/14)

${ }^{7}$ Fishman (2000) 160-61.

${ }^{8}$ Adams (2006) 96.

${ }^{9}$ Hawke (1997) 633.
} 
teaching career. ${ }^{1}$ It is not student outcome centred when faculty do not have the the opportunity to participate in governance issues. Students suffer when the faculty do not have a "long-term investment in an institution" ${ }^{2}$ In 1970, adjuncts accounted for 22 percent of faculty. ${ }^{3}$ Today that percentage is approximately 42 percent. $^{4}$ "[A] continuously changing cadre of temporary and and part-time faces compromises collegiality, department operations, and the quality of education."5

Finally, our approach provides balance. While the long term contracts provide administrative flexibly, we were aware that if we completely eliminated tenure, we would lose the ability to attract and keep certain faculty. ${ }^{6}$ faculty. ${ }^{6}$

\section{Academic Freedom}

Tenured faculty who teach, research, and write about cutting edge or controversial issues often state that they would not have a job without the protection that tenure provides. ${ }^{7}$ Such tenure supporters are the living embodiment of the belief that tenure is the safeguard of academic freedom. ${ }^{8}$ Academic freedom allows for "professional autonomy and collegial selfgovernance." Faculty are free to "investigate, teach, and publish in their various areas of competence without fear of retaliation in pursuit of the truth in the realm of ideas." 10 Without tenure, the faculty member who is "diligent in teaching and brilliant in publication, yet who expresses controversial opinions in class or supports unpopular causes which are troublesome to the administration; whose contract, absent the protection of tenure, is simply not renewed at its expiration, forcing the professor to seek other employment because he exercised academic freedom." 11 Tenure supporters believe that tenure removes the fear that "McCarthy-esque harassment of academicians could occur subtly under the guise of one evaluation scheme or another." 12

We agree that Academic freedom is important. It allows faculty to benefit society with opinions and ideas that they might withhold "because of fear of offending a dominant social group or a transient social attitude." ${ }^{\prime 3}$ We believe

\footnotetext{
${ }^{1}$ Adams (2006) 96.

${ }^{2}$ Ibid.

${ }^{3}$ Angel (2000) 11.

${ }^{4}$ Ibid.

${ }^{5}$ Hawke (1997) 633.

${ }^{6}$ Hawke (1997) 632.

${ }^{7}$ Comments from American Bar Association Section of Legal Education and Admissions to the the Bar Program Session, on January 4, 2014 at 4 P.M., at The Association of American Law Schools Annual Meeting 2014: Looking Forward Legal Education in the $21^{\text {st }}$ Century.

${ }^{8}$ Robbins (1998) 389.

${ }^{9}$ Adams (2006) 72.

${ }^{10}$ Adams (2006) 73.

${ }^{11}$ Hawke (1997) 621.

${ }^{12}$ Robbins (1998) 389.

${ }^{13}$ Adams (2006) 73.
} 
that all faculty should have a "certain level of autonomy" when it comes to teaching materials, teaching methods and scholarship agendas. ${ }^{1}$

Our model works because the choice is with the faculty member. We asked our colleagues whether academic freedom was possible without tenure. Some faculty believed that it was possible, while others were a steadfast "no". Ideally, the institutional environment should be built on trust and faculty should work together to ensure academic freedom for all types of faculty members. ${ }^{2}$ But, the scholar who engages in controversial topics may opt for tenure. Others who do not want the burden of scholarship may opt for a different track. In each instance, the faculty member does not forgo governance and full participation in the institution. ${ }^{3}$

\section{Additional Considerations for Legal Writing and Skills Faculty ${ }^{4}$}

The debate concerning the benefits and pitfalls of tenure and non-tenure positions in higher education is not a new subject by any stretch of the imagination. Similarly, a law faculty member's status as a legal writing or skills professor, and the effect this status has on his or her career and experiences in the Academy has been equally addressed for many years. ${ }^{5}$ So, it should be of no surprise that at our legal writing and skills faculty also had specific concerns that needed to be addressed by our new Track system.

\section{The Legal Writing and Skills Professor in the Academia Hierarchy}

There are many similarities between the circumstance of the teacher in elementary school and the legal writing and skills faculty in the law school

\footnotetext{
${ }^{1}$ Robbins (1998) 389.

${ }^{2}$ O'Neil (2001) 579. "The schools that don't have tenure Hampshire thus remains the shining example - perhaps, indeed, the only example - of an institution at which academic freedom and due process appear to have been respected despite the absence of a formal system of faculty tenure. To understand better this anomaly, it would be helpful to know more than we do about the unique conditions under which Hampshire was founded - through a consortium of the four existing baccalaureate institutions in the central Connecticut River Valley, all of which retain traditional tenure systems while sharing faculty time and other academic resources with their new neighbor".

${ }^{3}$ Liemer (2004): "The general practice in law schools in the United States is for professors who have traditional tenure or are on the traditional tenure track to vote on all matter at faculty meetings. Non-tenure track visitors and adjuncts generally do not attend faculty meetings and do not vote. Fellows who teach some classes while working on graduate law degrees and students who serve as teaching assistants also usually do not attend faculty meetings and do not vote. It is much more difficult, however, to generalize about full-time faculty who teach in the law school clinics, legal writing programs, and libraries."

${ }^{4}$ Clinical faculty will not be a focus during this discussion because, under the original more traditional model, that faculty did not have the same concerns as the legal writing and skills faculty at our institution because they had more equitable pay, full rank faculty status, and tenure option.

${ }^{5}$ Liemer and Temple (2008) 385: "Nonetheless, it is no secret that most law school faculties in in the United States have well-defined hierarchies and that legal writing professors often are relegated to low positions within those hierarchies." (Footnotes omitted)).
} 
setting. In the elementary school area, there has been a long term struggle to attract male teachers. ${ }^{1}$ This struggle to attract male teachers arguably further contributes to a pay disparity between the elementary teaching salary and the middle or high school teaching salaries. "A change in the gender imbalance could sway the way teaching is regarded. Jobs dominated by women pay less on average than those with higher proportions of men, and studies have shown that these careers tend to enjoy less prestige as well."2

A similar concern about attracting male legal writing faculty and pay differential of legal writing faculty exists in the legal academy.

"[T]he legal academic hierarchy is clearly gender based and accomplishes a stark gender segregation and division of labor within the academy. Women dominate the lower ranked legal writing positions, and men dominate the highly ranked doctrinal positions. In this hierarchy, the relationship between the categories (and sexes) is one of exploitation, with legal writing presumed to be uninteresting, unintellectual 'women's work' and doctrinal teaching presumed to be highly intellectual, challenging and, therefore, masculine."

What followed, like in the elementary school sphere, has been less pay and, in many cases with the absence of tenure or long term contracts, less job security and respect for the legal writing professors. We were no different from the national trend in this area.

\section{The Impetus to Change}

Our administration and faculty had begun to make positive changes for legal writing and skills faculty prior to our charge in 2013. As such, by 2013, the ground was fertile for change. First, in 2010, after the abrupt departure of the Director of Legal Writing, the administration supported the legal writing faculty when they opted to develop a collaborative operation model, rather than hire a new Director. Under the collaborative model, there was no longer a "boss" over the faculty whom students could run to or the administration would rely on to be the sole voice of the legal writing faculty. Students and the administration had to communicate with each individual faculty member. This empowered the faculty to find their voice and become more engaged in the institution. The collaborative model is still in place after nearly five years and it is well-regarded by the administration and faculty as a whole. In fact, the

\footnotetext{
${ }^{1}$ Gormley (2013) "Higher wages for teachers could help. But higher pay could be a consequence, not a cause, of more male teachers. As Stanford professor Paula England has found, wages tend to be lower, on average, in female-dominated professions. With more males in teaching, wages for men and women might rise."

${ }^{2}$ Rich (2014).

${ }^{3}$ Stanchi (2004) 477-78.This pay differential is entirely based on membership in the group labelled "legal writing professors.".
} 
faculty and legal writing program have thrived under this structure of equal collaboration, self-governance and creativity.

Secondly, because curricular needs, several members of the legal writing faculty began to teach courses outside of the legal writing sphere and proved to be very competent. Accordingly, it was only logical that their colleagues would begin to value and respect the input of the legal writing faculty, and that the legal writing faculty would fully appreciate their value and have an expectation to be treated equally. As Susan Liemer and Jan Levine noted

"[s]chools that do commit the necessary resources [toward legal writing] receive a significant return on their investment. Writing professionals dedicate their careers to the future quality of legal writing. They gain experience and expertise in teaching legal writing. They discover new ways to teach key lawyering skills [. . .]. They teach courses at the law school, work on faculty committees, and provide service to the bench and bar. Of course, they are able to better train tomorrow's attorneys, judges, and legislators." 1

In addition to the collaborative organisational structure and teaching opportunities outside of legal writing, there were other beneficial processes and circumstances already in place that further supported the transition to the new Track system. As a young law school, we have had the benefit of knowledge about the struggles and concerns of faculty that occur in other law schools. Accordingly, in contemplating the role of our faculty, our founders and inaugural faculty members attempted to eliminate any injustice or feelings of inequality by any one group by instituting several practices. All rank faculty, regardless of status as tenure or contract faculty, have the faculty vote and governance of the institution. Additionally, all faculty have the opportunity to seek a summer stipend or a research assistant regardless of whether he or she was contractually obligated to publish.

A few years ago, the faculty decided to combine the search and hiring process for legal writing/skills/clinical faculty with the doctrinal process so that doctrinal had a vote on the hiring of clinical/skills/legal writing faculty and vice versa. We were also cognisant of the fact that without the possibility of tenure, the skills and legal writing faculty needed some job security; accordingly, skills and legal writing faculty ${ }^{2}$, after a one-year probationary period, were eligible to seek a 3-year and then a 5-year long-term contract.

Yet, despite all these efforts, there still existed a feeling of inequity among many of the skills and legal writing faculty ${ }^{3}$ because their take-home salary was significantly less than that of the tenure track faculty. As Kathryn Stanchi recognised,

\footnotetext{
${ }^{1}$ Liemer and Levine (2003) 126-127.

${ }^{2} \mathrm{~A}$ few clinical were originally hired under the doctrinal model because they also taught podium courses, but opted to switch to teaching track once the new model was instituted.

${ }^{3}$ Clinical faculty's salary is more commiserate with tenure track faculty; however, the clinical faculty worked under a 12- month as opposed to the 10- month contract for tenure track.
} 
[n]o evaluation of merit occurs beyond the presumption of merit based on group membership. Much like in other institutionalised systems of dominance and discrimination, no external "objective" evidence of merit-teaching excellence, scholarship, years, or quality of law practice - can overcome the stigma of membership in the low status group. Even the primary credentials that purportedly carry so much weight in the legal academy, prestige of law school and participation on the law review, cannot overcome the presumptive lower status of legal writing. A legal writing professor who graduated from a top tier law school and served on the law review would still make less money ( $\$ 30,000$ less) than a torts professor who went to a third tier law school and had no law review experience. $^{1}$

The legal writing faculty's morale was still adversely affected by the perceived illogicalness of lesser pay despite the efforts of our institution to address the traditional "pitfalls" of inequity. Although it was beneficial that the legal writing faculty were furnished with the opportunity to teach outside of the legal writing realm, the practical result of taking on this third course actually highlighted the pay disparity. When the legal writing faculty took on another class, it was usually as an overload and he or she was paid the rate of overload pay. The overload pay still did not come close to closing the gap between legal writing and doctrinal faculty take home pay despite the extra course load.

Furthermore, although combining the hiring process yielded many positive results, the process also highlighted a few negatives with the position of a skills and legal writing faculty at our institution. For example, a combined process fostered a greater understanding of and respect for each other's teaching area. And, there was an increase feeling of ownership for both the direction of the school and in the development of new faculty members. However, the combined process also showed that the quality and quantity of experience of the legal writing and skills faculty applicants were equivalent with that of the doctrinal faculty applicants. This realisation further caused some skills and legal writing faculty to feel resentful for not receiving, or offering to a faculty applicant, equal yearly compensation.

Legal writing and skills faculty were also expected to and sought to actively participate in the service to the institution with the same amount of time and energy as the doctrinal faculty by: serving on multiple faculty committees (even chairing several of them); actively participating in studentrun organisations and competitions; and attending all faculty meetings. Again, given their time commitment and leadership, legal writing and skills faculty felt the disparity in pay was unjustified.

As a result of the above understandings and realisations, the legal writing and skills faculty members believed that the only difference between them and the doctrinal faculty was the publishing obligation under their contracts. And,

\footnotetext{
${ }^{1}$ Stanchi (2004).
} 
as discussed previously, the doctrinal faculty were not publishing at a consistent rate or volume as would be expected given the pay disparity. In fact, some members of the legal writing faculty had successfully published without contractual obligation or the compensation. So, if that was the reason for the disparity, it was not a good one. This dissatisfaction was the impetus for many of the changes reflected in the new model. Accordingly, the Track system needed to address the continued feelings of inequity and disparity amongst this sector of faculty in order to be successfully embraced by the entire faculty.

We believe our Track system is a win for the administration, faculty and students. We have reduced the number of adjuncts that we need by allowing doctrinal faculty who were not engaged in scholarship to teach more courses. We have improved collegiality because we have reduced "back door deals," removed issues of status by providing pay equity, and given all faculty the ability to receive rank promotion and ability to have security of position. Additionally, the long term renewable contracts are "an incentive to good performance, and will eliminate deadwood. They permit institutional flexibility in planning, budgeting and program development, and enable the college to terminate those who do not respond to current needs, and reappoint those that do." "Routine reappointments make term contracts resemble the institution of tenure. In fact, the term contract approach, in the words of a president of an institution with such a system, is a really instant tenure."

\section{PART III. Survey Results and Moving Forward}

\section{The Results}

A year after faculty selected a track and worked on that track, we conducted another anonymous survey. We sought feedback on each individual faculty member's understanding of the track system and his or her satisfaction

\footnotetext{
${ }^{1}$ Fishman (2000) 194.

${ }^{2}$ Fishman (2000) 195: "There are doubtless other examples of alternatives to tenure. One that seems to have worked reasonably well for three decades is that of Hampshire College, which has never offered tenure but has relied entirely on long-term renewable faculty contracts. Hampshire is reputed to have denied reappointment or renewal beyond the seven-year period that would require an "up or out" decision at most tenure-track institutions. Yet there is no evidence that abridgment of academic freedom, or denial of due process, has ever been validly charged against Hampshire, and there has been no formal AAUP investigation, much less censure. Such a non-reappointment beyond the seventh year is not vulnerable, under AAUP standards, at Hampshire so long as the process comports with the College's own regulations, and so long as the basis for such adverse action would not be deemed violative of academic freedom within the conventional tenure system. O’Neil (2001) 578-79: "We do know at least two highly significant things. First, from the very start, faculty members joined Hampshire without any expectation of tenure, so that those for whom formal protection of academic freedom would have seemed essential may simply have chosen not to teach there. Second, we also know that a generation of Hampshire presidents and governing boards has insisted on protecting academic freedom as fully without tenure as have their colleagues and counterparts at Amherst, Mount Holyoke, Smith, and the University of Massachusetts."; Ibid. at 579.
} 
with the system and their choice. Accordingly, we inquired about the strengths of the chosen track; the weaknesses of the chosen track; their opinions on whether they were in a better position this year on their track; and whether they would change tracks now if they could do so.

At the time of our survey we had 50 rank faculty, and 41 rank faculty filled out the survey. ${ }^{1}$ The survey revealed that a majority of the faculty understood the responsibilities and obligations under his or her chosen track. ${ }^{2}$ The survey further revealed that $85 \%$ of our faculty were either "very satisfied" or "satisfied" with their choice of track. ${ }^{3}$ Next we inquired whether or not they would change their track if they could, and more than half our faculty responded "no" to this question. ${ }^{4}$ Finally, we asked whether the individual faculty member felt they were in a better position, and this is where the survey had mixed results ${ }^{5}$ because a majority felt there was no difference. ${ }^{6}$

The survey also provided an opportunity for the faculty member to write specific comments. Some of the positive comments were:

"I was able to teach the classes I was hired to and able to teach."

"Not feeling pressure to find time to research and write."

"It allows me to teach a greater variety of courses."

"I have to pull my weight in terms of teaching load, but I can also progress as a traditional legal academic."

"I like teaching and that is where I naturally spend more time, so it makes sense for that to be the focus of my employment."

"Allows all faculty members the same opportunities for teaching/compensation, in terms of doctrinal/LP (legal writing) and allows faculty who are passionate about teaching, but perhaps not scholarship, to just pursue teaching."

"Alternative track allows me to keep some sanity - stay fulfilled professionally but not at the sacrifice of taking care of my family. This track also allows me to be more available to my students and stay energised for my students, less burnout."

"The clinic/teaching track allows clinicians to focus on their experiential work without worrying about traditional scholarship."

\footnotetext{
1 In the survey, we also had six Bar Prep and Academic Success Professional Track respondents.

$272.34 \%$ (34 faculty) responded "yes"; 27.665 (13) responded "for the most part, but I still have some confusion"; no one responded "no."

${ }^{3} 42.55 \%$ (20) responded "very satisfied"; $42.55 \%$ (20) responded "satisfied"; and 14.89\% (7) responded "unsatisfied."

${ }^{4} 10.64 \%$ (5) responded "yes, they would change"; $55.32 \%$ (26) responded "no, they would not change"; and 34.04\% (16) responded "maybe."

${ }^{5}$ We surmised that this unexpected result was because $2 / 3^{\text {rd }}$ of the doctrinal faculty remained tenure track, a few legal writing professors opted for alternative track to remain status quo, and the clinicians already were on a year-long teaching track with equitable compensation so for many of our faculty, there was no change.

$621.28 \%$ (10) responded "yes, in a better position"; $17.02 \%$ (8) responded "not in a better position"; and $61.70 \%$ (29) responded "they felt no difference."
} 
"The freedom to incorporate scholarship at my convenience. The ability to focus on what I really enjoy doing - teaching."

"Lends credibility to the institution and allow us to be creative and competitive in the academic world."

Included in what we considered more critical or negative comments were:

"Teaching 16-18 credit hours can be overwhelming."

"It is easy to tack on an extra hour or two onto those on the teaching track (which may equate to an additional course, in addition to large section 4 hour course); this can lead to feeling as if you are always teaching an overload without additional compensation."

"Still working out what the details of the steps to promotion are going to look like."

"The combo of Edge (new curriculum) has increased the teaching load for tenure track faculty, which will make it harder for our scholarship obligations to be promoted."

" 14 credit hours is a lot, 12 is reasonable."

"I believe it is difficult to actually measure the work I do by credits taught/earned, due to the heavy administrative obligation."

The comments helped us to "zero in" on the areas that we needed to address, and we recognise that as with any change there is need for improvement.

\section{Going Forward}

Although the data suggests that the faculty are satisfied overall with the Track system, in practice we recognise that there are several areas where there is room for improvement. For example, faculty were asked to elect a track; however, in attempting to maintain the balance between the tracks, not all faculty were put on the track they elected. Specifically, we had nine faculty who were either tenured or on tenure track switch to teaching track. But, this number was not enough to allow openings on the tenure track for clinical, skills and legal writing faculty.

As a result, clinical, skills and legal writing faculty either opted for alternative track (status quo for legal writing and skills) or choose teaching track. However, we recognise that some faculty enjoy scholarship; and, although we offer summer research stipends to all faculty to encourage scholarship on all tracks, we want to place each faculty member where he or she is happy and productive. Accordingly, we would like to offer clinicians, skills and legal writing faculty the option to switch to tenure track.

Although we have some faculty who are producing scholarship who wanted to switch to tenure track, we have some tenure track faculty who opted to remain on tenure track but are not producing at an appropriate rate. The danger is they will try to use the track system as a last minute escape to their 
contractual obligation under tenure track. After benefiting from a lighter teaching load than the teaching track, a non-producing tenure track faculty may attempt to use his or her years of teaching to solicit rank promotion and extended contract on a different track. Currently the Dean has the discretion to grant transfers between tracks. However, in order to maintain the even distribution of faculty on each track and to ensure that one track is not perceived as a scapegoat when contractual obligations are not met, the Dean is advised to approve such requests sparingly.

Another area that deserves close attention is the workload. The track system required the buy-in of the faculty and the administration. While the faculty pushed for increased pay, the administration was concerned about the inability to hire additional full time faculty in the current legal climate. After adopting the new curriculum, there were more core courses that needed fulltime faculty coverage. As a result, faculty on each of the tracks are required to teach more credit hours per year. With the constraints on legal education today, we, like most schools, are not in a position to hire additional full-time faculty.

Another one of the concerns raised by the increase in the teaching load is overburdening inexperienced or less gifted teachers who cannot handle the additional teaching responsibilities. Student engagement and outcomes remain a core responsibility for each of us, so we want to make sure that our faculty is delivering quality instruction to the students. Our faculty mentoring and development committee observes and provides formative feedback to each faculty member. In addition, the committee offers best practice sessions that focus on issues related to teaching and delivery. Some sessions have included how to provide feedback; how to integrate writing in podium classes; how to fairly grade and create rubrics; and faculty accountability, to name a few.

The final area that needs fuller development is hybrid faculty. These faculty, clinicians and experiential faculty, carry both administrative and teaching responsibilities. Credit hours under the current track system are difficult to calculate for this group of faculty. As a result, in close consultation with the clinicians and experiential faculty we had to create a specific clinical teaching and tenure track system. ${ }^{1}$ In addition, unlike other faculty, the clinical and experiential faculty are employed year-round. This makes calculating yearly teaching credits difficult when we want to ensure equity for all types of faculty. We also recognise that litigation clinics require more administrative responsibilities due to obligations to the court that may not conform to an academic calendar. We continue to work with administration and faculty.

Despite the areas that need to be fine-tuned, the Track system has benefited our faculty, administration and students.

\footnotetext{
${ }^{1}$ We currently have no clinicians or experiential faculty on tenure track. But, a tenure model would encompass teaching their clinical program, producing scholarship and perform administrative duties throughout the calendar year. The clinicians on teaching track teach 1 clinical program plus another podium course and perform administrative duties throughout the calendar year.
} 


\section{References}

Adams, M.L. (2006). 'The Quest for Tenure: Job Security and Academic Freedom', 56 Cath. U. L. Rev. 67.

Am. Bar Association Task Force on the Future of Legal Education, Report and Recommendations 1 (2014), available at htttp://www.americanbar.org/content/ dam/aba/administrative/professional_responsibility/report_and_recommendations_ of_aba_task_force.authcheckdam.pdf, archived at http://perma.cc/373L-FW83.

Am. Bar Association. Task Force on the Future of Legal Education (2014). http://ww w.americanbar.org/groups/professional_responsibility/taskforceonthefuturelegaled ucation.html, archived at http://perma.cc/P3TK-CTYN (last visited 10/12/14).

Angel, M. (2000). 'The Glass Ceiling for Women in Legal Education: Contract Positions and the Death of Tenure', $50 \mathrm{~J}$. Legal Educ. 1.

Conrad, R.B. and L.A. Trosch (1998). 'Renewable Tenure', 27 J.L. \& Educ. 551.

Dunham, C. and S.I. Friedland (2009). 'Portable Learning For The 21st Century Law School: Designing A New Pedagogy For The Modern Global Context', $26 \mathrm{~J}$. Marshall J. Computer \& Info. L. 371.

Feldman D. and W. Turnley (2001). 'A field study of Adjunct Faculty: The Impact of Career Stage On Reactions to Non-Tenure Track Jobs', 28 Journal of Career Development 1, Fall 2001;

Figlio, D.N., Schapiro, M.O. \& K.B. Soter (2003). 'Are Tenure Track Professors Better Teachers?, National Bureau of Economic Research', September 2013, available at http://www.nber.org/papers/w19406.

Fishman, J. (2000). 'Tenure and Its Discontents: The Worst Form of Employment Relationship save All of the Others', 21 Pace L Rev. 159.

Friedman, N. (2009). Department of Education: National trend favors untenured faculty, Brown Daily Herald, Feb. 18, 2009 (via U-Wire);

Gromley, W. (2013). 'What our Schools need? A Few Good Men', USA Today, Aug. 13,2013

Hawke, C. (1997). 'Tenure's Tenacity in Higher Education', 120 Ed. Law Rep. 621.

Holbrook, J. R. (2013). 'Reflections on the Future of Legal Education', Utah L. Rev. 53.

Kiehl, S. (2000). ‘Teachers seek Job Security at Tenure-Free University’ Palm Beach Post, June 10, 2000.

Liemer, S.P. (2004). 'The Hierarchy of Law School Faculty Meetings: Who Votes?', 73 UMKC L. Rev. 351.

Liemer, S.P. and H.S. Temple (2008). 'Did Your Legal Writing Professor Go To Harvard?: The Credentials of Legal Writing Faculty at Hiring Time', $46 \mathrm{U}$. Louisville L. Rev. 383.

Liemer, S.P. and J.M. Levine (2003). 'Legal Research and Writing: What Schools Are Doing, and Who Is Doing The Teaching (Three Years Later)', 9 Scribes J. Legal Writing 113.

Mangan, K. (2013). 'Panel Suggests Dropping Tenure Requirement to Reform Legal Education', The Chronicle of Higher Education, Sept. 20, 2013 (http://chronicle.com/article/Panels-Idea-for-Reforming/141763).

Newbart, D. (1996). 'Academic Staff at UW Seek Respect', The Capital Times, October 11, 1996, at 1A

Newton, B.E. (2010). 'Preaching What They Don't Practice: Why Law Faculties' Preoccupation With Impractical Scholarship And Devaluation Of Practical Competencies Obstruct Reform In The Legal Academy', 62 S.C. L. Rev. 105. 
O’Neil R. M. (2001). 'Alternatives to Tenure', 27 J.C. \& U.L. $573 .$.

Rich, M. (2014). 'Why Don't More Men go Into Teaching?', N.Y. Times, Sept. 6, 2014.

Robbins, I.P. (1998). 'Exploring the Concept of Post-Tenure Review in Law Schools', 9 Stan. L. \& Pol'y Rev. 387.

Schmidt, P. (2013). 'Business School Offers Case Study for Tenure Debate,' The Chronicle of Higher Education, Nov. 15, 2013.

Stanchi, K. (2004). 'Who Next, The Janitors? A Socio-Feminist Critique of The Status Hierarchy of Law Professors', 73 UMKC L. Rev. 467.

Stewart, J. B. (2014). 'A Bold Bid to Combat a Crisis in Legal Education', N.Y. Times, April 4, 2014.

Tamanhale, B.Z. (2012). Failing Law Schools. The University of Chicago Press.

Willis, E. (2001). 'Why Professors Turn to Organized Labor', N.Y. Times, May 28, 2001, at A11. 